College of Engineering

Center for Environmental Research and Technology

University of California

Riverside, California

\title{
Hydrogen Fuel for Surface Transportation
}

\author{
Joseph M. Norbeck \\ James W. Heffel \\ Thomas D. Durbin \\ Bassam Tabbara \\ John M. Bowden \\ Michelle C. Montano
}

Published by:

Society of Automotive Engineers, Inc.

400 Commonwealth Drive

Warrendale, PA 15096-0001

U.S.A.

Phone: (412) 776-4841

Fax: (412) 776-5760 


\section{Library of Congress Cataloging-in-Publication Data}

Hydrogen fuel for surface transportation / Joseph M. Norbeck... [et al.].

p. $\mathrm{cm}$.

Includes bibliographical references and index.

ISBN 1-56091-684-2

1. Hydrogen cars. 2. Hydrogen as fuel. 3. Fuel cells.

I. Norbeck, Joeseph M., 1943-

TL229.H9H94 1996

629.25'38--dc20

96-38602

CIP

Copyright $\odot 1996$ Society of Automotive Engineers, Inc.

ISBN 1-56091-684-2

All rights reserved. Printed in the United States of America.

Permission to photocopy for internal or personal use, or the internal or personal use of specific clients, is granted by SAE for libraries and other users registered with the Copyright Clearance Center (CCC), provided that the base fee of $\$ .50$ per page is paid directly to CCC, 222 Rosewood Dr., Danvers, MA 01923. Special requests should be addressed to the SAE Publications Group.

$1-56091-684-2 / 96 \$ .50$

SAE Order No. R-160 


\section{Dedication}

To Dr. Robert M. Zweig, whose longstanding commitment to the advancement of hydrogen as a clean fuel

has been a source of inspiration to many 



\section{Contents}

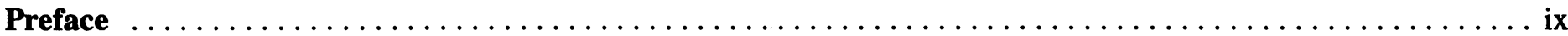

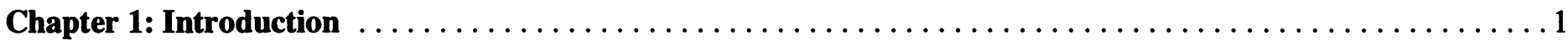

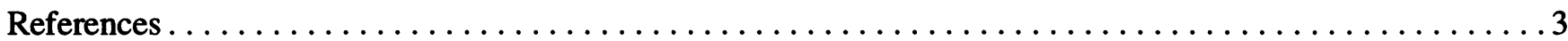

Chapter 2: Hydrogen Engines and Vehicles: Characteristics and Development $\ldots \ldots \ldots \ldots \ldots \ldots \ldots \ldots$

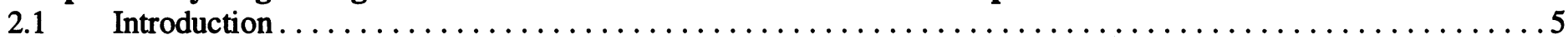

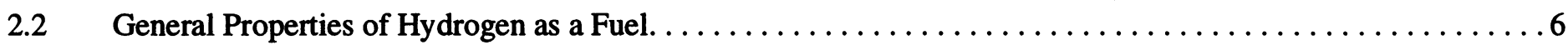

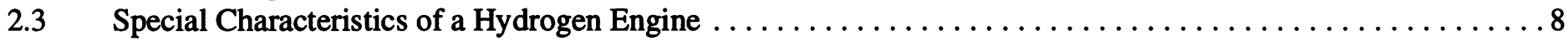

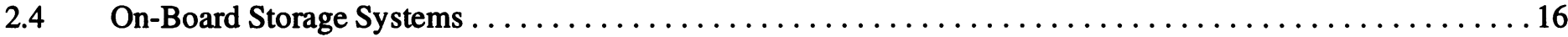

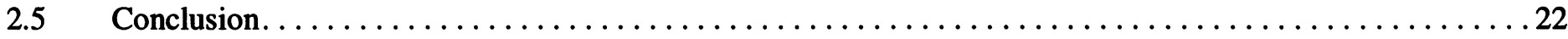

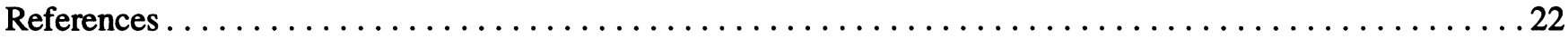

Reprints:

Fuel Induction Techniques for a Hydrogen Operated Engine

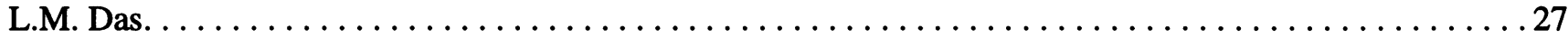

Trend of Social Requirements and Technological Development of

Hydrogen-Fueled Automobiles

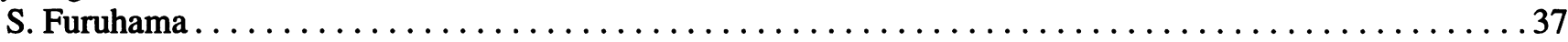

Hythane-An Ultraclean Transportation Fuel

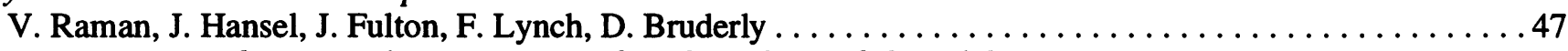

Germany's Contribution to the Demonstrated Technical Feasibility of the

Liquid Hydrogen Fueled Passenger Automobile

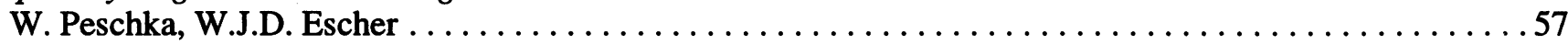

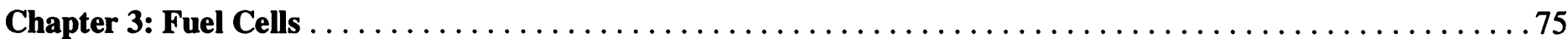

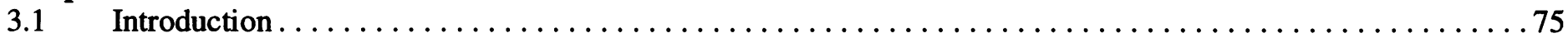

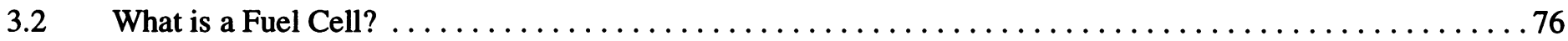

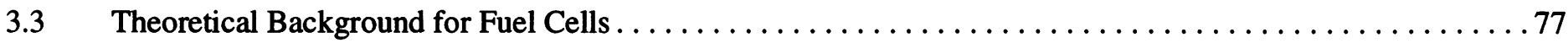

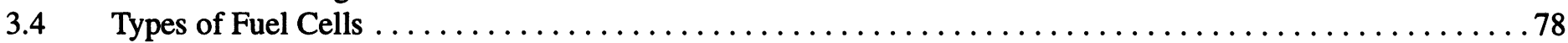

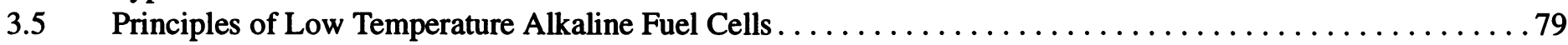

3.6 The Solid Polymer Fuel Cell or Proton Exchange Membrane Fuel Cell $\ldots \ldots \ldots \ldots \ldots \ldots \ldots \ldots \ldots \ldots$

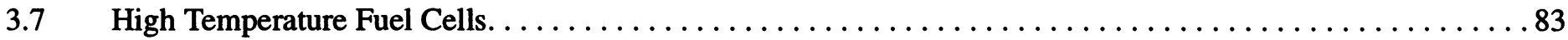

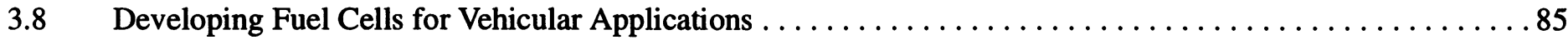

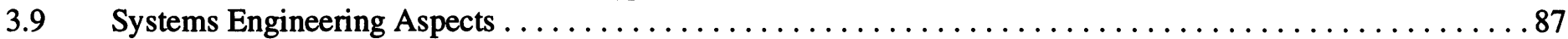

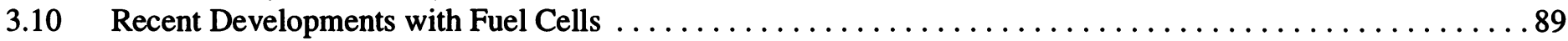

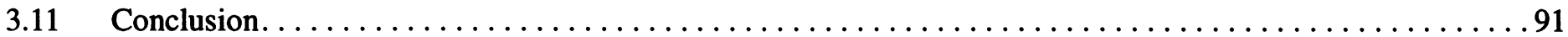

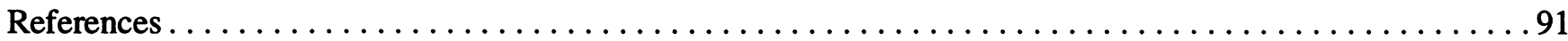

Reprints:

Hydrogen-Air Fuel Cells of the Alkaline Matrix Type: Manufacture and

Impregnation of Electrodes

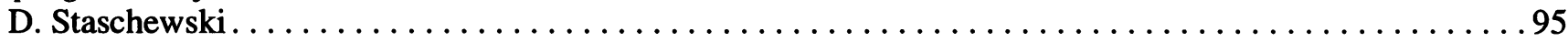

High-Temperature Fuel Cells; Part 1: How the Molten Carbonate Cell Works

and the Materials That Make it Possible

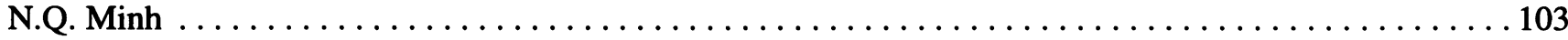

High-Temperature Fuel Cells; Part 2: The Solid Oxide Cell

N.Q. Minh 
Hydrogen from Methanol: Fuel Cells in Mobile Systems

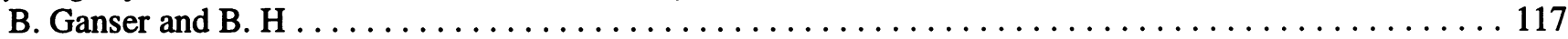

Phosphoric Acid Fuel Cell Bus Development

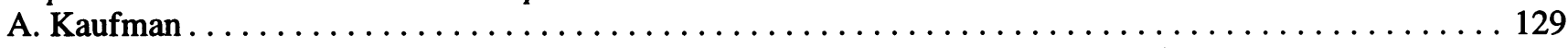

Proton Exchange Membrane (PEM) Fuel Cell System R\&D for Transportation Applications

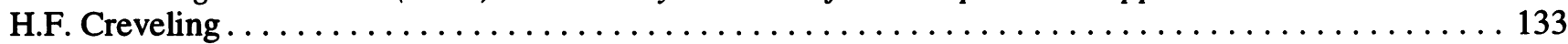

Core Technology $R$ \& D for PEM Fuel Cells

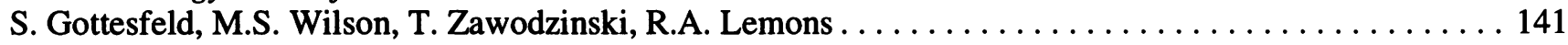

Recent Progress in Proton Exchange Membrane Fuel Cells at Texas A\&M University

N.K. Anand, A.J. Appleby, H.P. Dahr, A.C. Ferreira, J. Kim, S. Mukerjee, et al. . . . . . . . . . . . 147

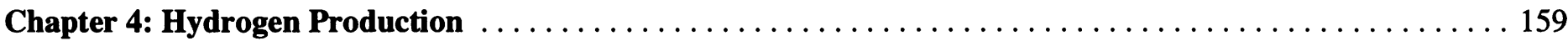

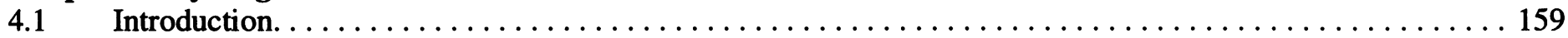

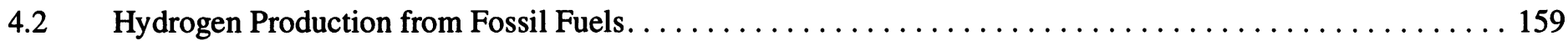

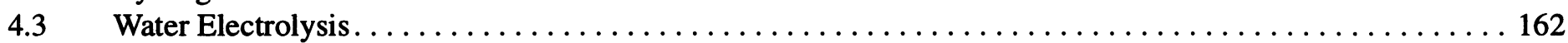

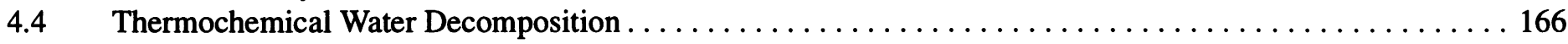

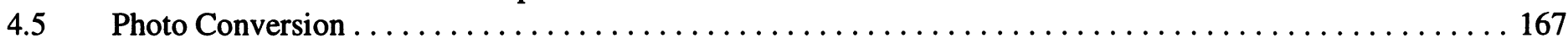

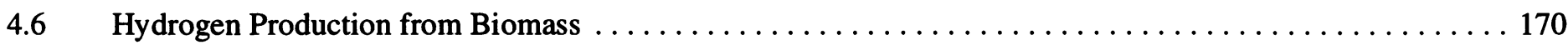

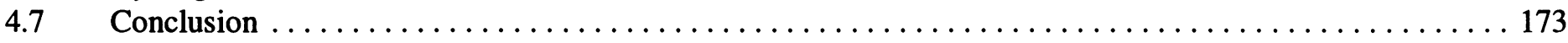

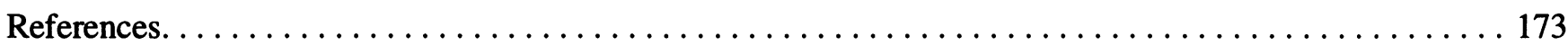

Reprints:

Modern and Prospective Technologies for Hydrogen Production from Fossil Fuels

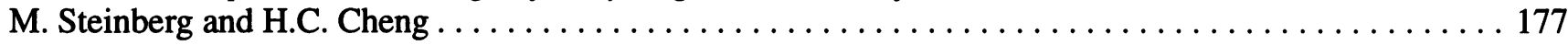

Technology Assessment of Advanced Electrolytic Hydrogen Production

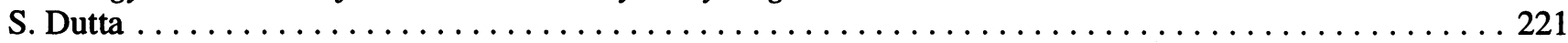

Economical and Technical Evaluation of UT-3 Thermochemical Hydrogen

Production Process for an Industrial Scale Plant

A. Aochi, T. Tadokoro, K. Yoshida, H. Kameyama, M. Nobue, and T. Yamaguchi . . . . . . . . . . . . 229

Photoelectrochemical and Photocatalytic Methods of Hydrogen Production: A Short Review

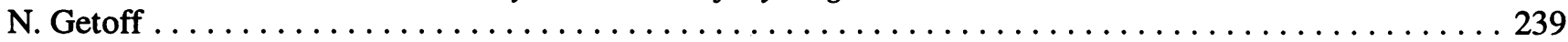

Hydrogen Production by Cyanobacteria

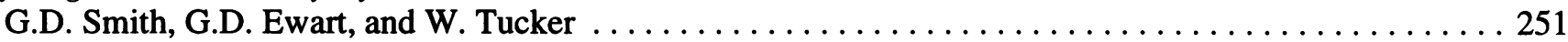

Pine and Willow as Carbon Sources in the Reaction Between Carbon

and Steam to Produce Hydrogen Gas

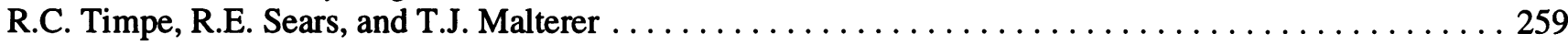

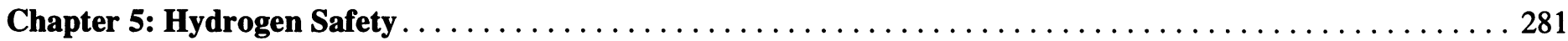

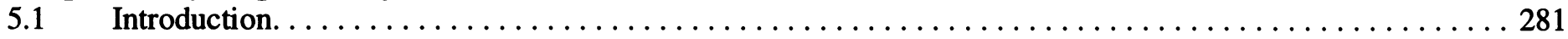

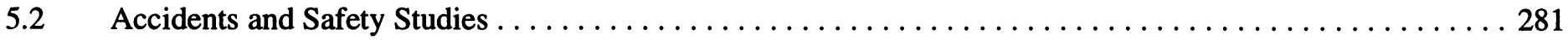

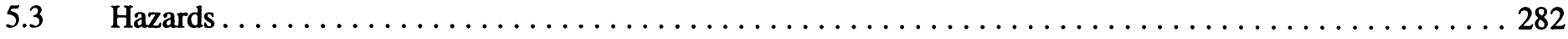

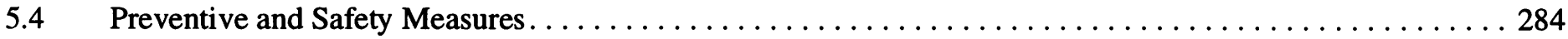

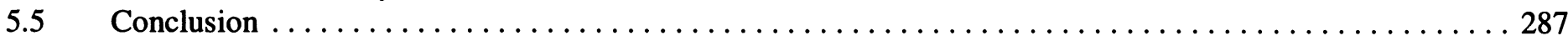

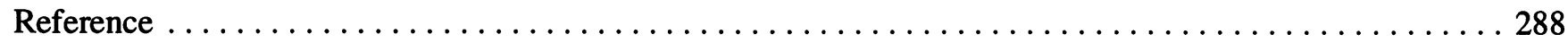

Reprints:

Aspects of Safety and Acceptance of $\mathrm{LH}_{2}$ Tank Systems in Passenger Cars

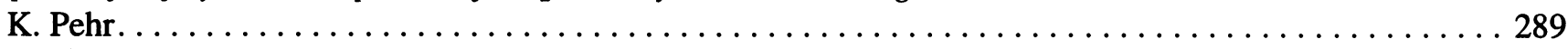

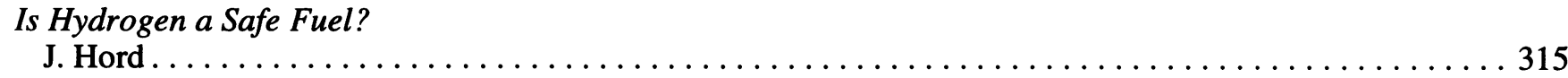

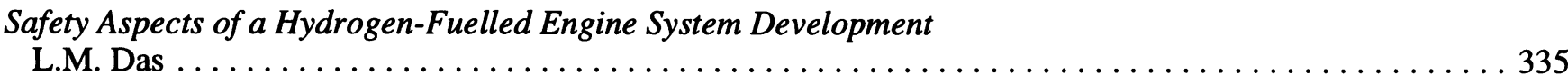

Safety Aspects of Hydrogen Combustion in Hydrogen Energy Systems

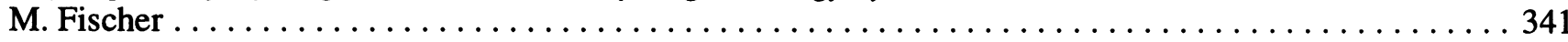




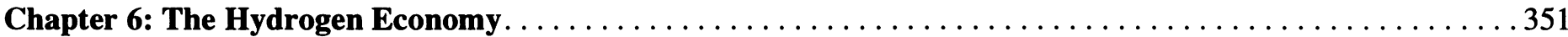

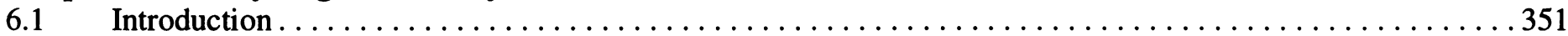

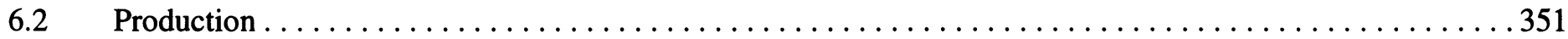

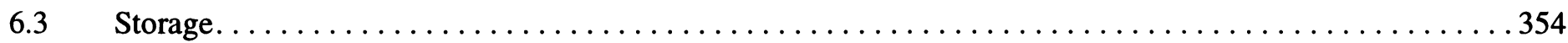

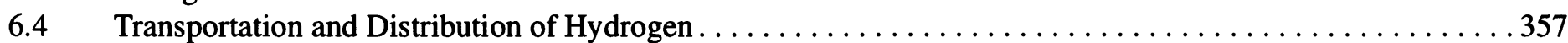

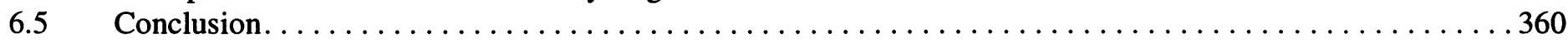

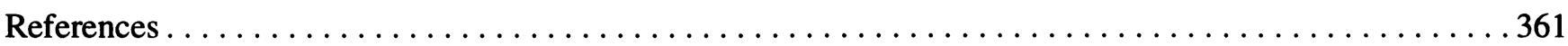

Reprints:

Economics of Hydrogen as a Fuel for Surface Transportation

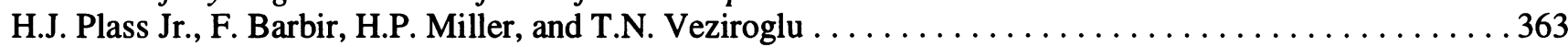

Renewable Hydrogen Transportation Fuels

J.M. Ogden and M.A. Deluchi . . . . . . . . . . . . . . . . . . . . . . . . . . . . . 369

Technical and Economic Assessment of Methods for the Storage

of Large Quantities of Hydrogen

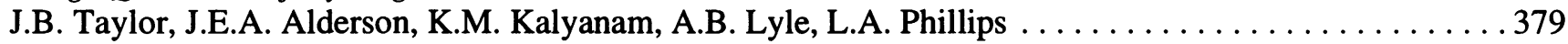

Chapter 7: Hydrogen Vehicles: From Earliest Conception to the Present $\ldots \ldots \ldots \ldots \ldots \ldots \ldots \ldots \ldots \ldots$

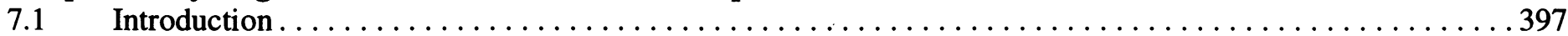

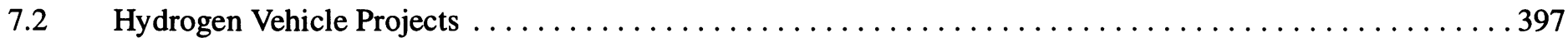

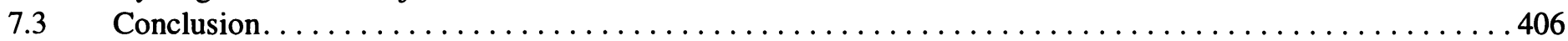

References ............................................4406

Reprints:

Development of a Hydrid Fuel Cell/Battery Powered Electric Vehicle

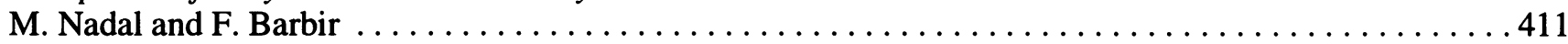

Preliminary Evaluation of UC Riverside's Hydrogen Powered Truck

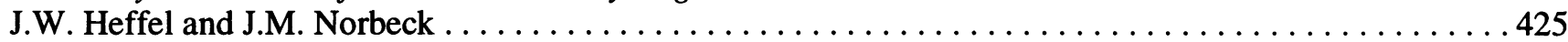

Solid Polymer Fuel Cell Developments at Ballard

K.B. Prater . . . . . . . . . . . . . . . . . . . . . . . . . . . . . . . . . . . . . . . . . . . . . 437

HYPASSE - Hydrogen Powered Automobiles using Seasonal and

Weekly Surplus of Electricity

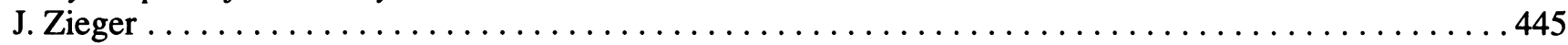

Current Development and Outlook for the Hydrogen-Fuelled Car

D. Reister and W. Strobl .......................................... 455

Some Performance of Engine and Cooling System on $\mathrm{LH}_{2}$ Refrigerator Van Musashi-9

K. Yamane, M. Hiruma, T. Watanabe, T. Kondo, K. Hikino, T. Hashimoto, S. Furuhama . . . . . . . . . . . 469

Combustion Characteristics in Hydrogen Fueled Rotary Engine

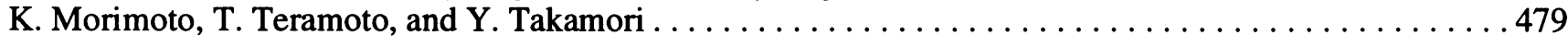

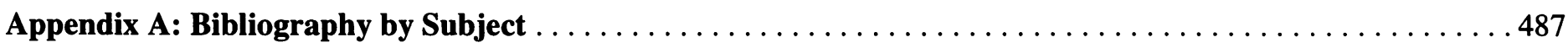

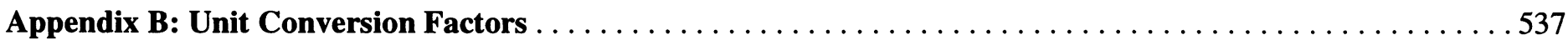

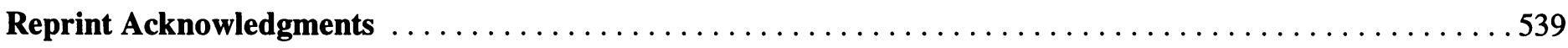

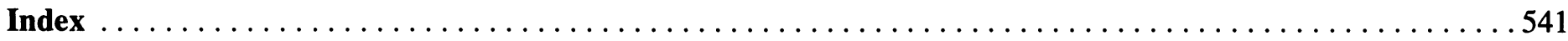





\section{Preface}

This book has been written as part of an ongoing program in hydrogen fuel for surface transportation at the College of Engineering - Center for Environmental Research and Technology (CE-CERT) at the University of California, Riverside. Faculty, students, and staff who are working with new technologies for hydrogen production and hydrogen-fueled vehicles have developed this book as a comprehensive overview, reference, and database on the subject. The book provides background information on the advantages and disadvantages of hydrogen as a fuel for surface transportation, describes the current state of technology of hydrogen-fueled vehicles, and discusses the future requirements of the so-called "hydrogen economy." We believe that the reprints and introductory material of each chapter will be invaluable to new and experienced researchers in the field.

The hydrogen program at CE-CERT is directed by Joseph M. Norbeck, CE-CERT's Director, and Project Manager James W. Heffel. The development of this book was supervised by Steven E. Belinski, who was also the primary editor. The following individuals were responsible for writing the individual chapters: Thomas D. Durbin contributed to all the chapters; Bassam Tabbara contributed to Chapters 3, 6, and 7; John M. Bowden contributed to Chapters 4 and 6; and Michelle C. Montano contributed to Chapter 5. Helen Ku assisted with the preparation of the final manuscript.

This book is based on information collected in a comprehensive literature survey which was performed as part of a larger project funded by the South Coast Air Quality Management District (SCAQMD). The opinions, findings, recommendations and/or conclusions do not necessarily represent the views of the SCAQMD. The SCAQMD has not approved or disapproved of this book's contents, nor has the SCAQMD passed judgement upon the accuracy or adequacy of the information presented herein.

Since the field of hydrogen for surface transportation is evolving so rapidly, information on current developments in the field of hydrogen-fueled vehicles and the hydrogen economy can be obtained directly from CE-CERT at (909) 781-5791.

Joseph M. Norbeck

James W. Heffel

Thomas D. Durbin

Bassam Tabbara

John M. Bowden

Michelle C. Montano

Riverside, California

April 1995 